\title{
Mapping of Human Resource Characteristics of MSME in Pandeglang District, Pandeglang Regency, Banten Province
}

\author{
Renny Husniati, Alnisa Min Fadillah \\ Management Study Program of the Faculty of Economics \& Business, UPN Veteran \\ Jakarta \\ Email: renyhusniati@upnvj.ac.id; Alnisa.upn@gmail.com
}

Received: November $14^{\text {th }} 2019$

Approved: June $25^{\text {th }} 2020$

\begin{abstract}
Human resources (HR) is one of the most important factors that cannot be separated from an organization, both an institution and a company. HR is also a key that determines the development of the company. Errors in the selection of human resources will adversely affect the achievement of organizational goals. Human resources must be empowered with the management and development or also called human resource management. This study aims to gather information regarding HR at MSMEs in Pandeglang Regency and how these characteristics can influence the development of the business being run. From the results of the mapping of HR characteristics, it is expected to be of use to the relevant department, by obtaining information on the potential of MSME in Pandeglang Regency by identifying and field surveys. Looking at the potential of Small Medium Enterprise (SME), a coaching program can be formulated so that an independent SME will be formed that can be developed to raise local excellence. For SME, it is an opportunity to develop their business through assistance and guidance in accordance with management needs. This mapping uses a survey method that is digging data through the distribution of questionnaires including data on HR characteristics and knowledge, skills and attitudes in managing a business. From the results of the study, it can be seen the average score of the three indicators, that is knowledge of 2.95, skills of 2.97 and attitudes of 3.05. This means that in managing a running business is good enough.
\end{abstract}

Keywords: Mapping, Human Resource Characteristics 


\section{Introduction}

Human Resources (HR) is an important asset for an organization to carry out its business activities (Dessler, 2017). HR is also the key to determine organizational development. Consequently, the organization needs to choose the right person for the right job or position. The accuracy of the selection is related to the characteristics (competencies) that the organization needs in accordance with the vision and mission and values that exist in the organization by adjusting to an individual or also called prospective workers (Wilson, 2012). High competence possessed by $\mathrm{HR}$ in an organization or company will certainly determine the quality of HR owned and, in the end, will determine the competitive company itself. The same is true for Micro, Small and Medium Enterprises (MSMEs), HR competencies also have an important role in the development of these MSMEs (Widjaya, 2018).

Competence is a set of complexities of productive elements such as expertise and skills in an organization that distinguishes it from competitors is all capabilities possessed by humans (Soemardjo, 2018). This means that an individual's competence includes the knowledge, skills, and attitudes they have that are different from other individuals.

The economic activities of the community or often more popular people's economy are actually synonymous with small, medium business activities. The people's economy is an economy that is related to ordinary people, not the government, not conglomerates and large capital holders, an economic activity carried out by most people. People's economy business refers to Law number 20 of 2008 classified into Micro and Small and Medium Enterprises with a limit on the amount of net assets owned and the achievement of sales volume/turnover.

Micro business is a type of small-scale business which is generally in the form of the informal sector. Considering the importance of the micro business sector, especially in providing employment, it is only natural that this business sector should be given more attention so that it can truly become a major buffer for the national economy.

The seriousness of the government to develop and empower MSME is increasingly clear with the promulgation of Law number 20 of 2008 on Micro, Small and Medium Enterprises, as an integral part of a people's economy that has a position, role, and strategic potential to realize a balanced, developing and equitable national economic structure. Empowerment needs to be carried out thoroughly, optimally and sustainably through a conducive climate in order to realize economic growth, as well as increase in income, job creation that can ultimately reduce poverty.

MSME is a labor-intensive business, does not require certain requirements such as the level of education, skills of workers, and the use of relatively little business capital and the technology used tends to be simple, but the activity of Micro, Small and Medium Enterprises (MSME) is one business sectors that can develop and are consistent in the national economy, so 
that MSMEs can be a good place to create productive employment (Ananda, 2017). SME, including holding an important role in efforts to improve the Indonesian economy, both in terms of the number of businesses, in terms of job creation (Handayani, 2018).

In Pandeglang District, Pandeglang Regency, Banten Province, 83 MSMEs have been registered and have SIUP in Pandeglang District, with various types of businesses. Besides having a very large contribution to regional income, influencing the regional icon as an embryo of the Pandeglang District. This has a very important role in the development of Pandeglang District, especially in the economic, trade and even tourism aspects. Therefore, it is the government's obligation to maintain and develop the business in various aspects so that MSMEs are more independent so that they have the same value as the types of businesses that have a larger scale. Through this mapping, it is hoped that a clearer picture of potential MSMEs can be obtained. The seriousness of the government to develop and empower MSMEs is increasingly clear with the promulgation of Law number 20 of 2008 on Micro, Small and Medium Enterprises, as an integral part of a people's economy that has a position, role, and strategic potential to realize a balanced, developing and equitable national economic structure. Empowerment needs to be carried out thoroughly, optimally and sustainably through a conducive climate in order to realize economic growth, and increase in income, job creation which can ultimately reduce poverty.

\section{RESEARCH METHODS}

The approach used in this research is a quantitative description method that describes Human Resources at MSMEs which includes gender, education, business profile, length of business, roles in business, duties and responsibilities in business with a frequency distribution table display and graph as a result of data processing. Meanwhile, to find out about knowledge, skills and attitudes in managing business, research data will be obtained through the distribution of questionnaires to SMEs in Pandeglang district arranged according to the desired scale of statements that are strongly disagree, disagree, agree and strongly agree given grades 1 to 4 that are used to measure the perceptions of SMEs about knowledge, skills and attitudes in managing a business. Each instrument is arranged in the form of a sentence statement with five alternative answers related to the research indicators. The items of the questionnaire are arranged in the form of statements that will measure knowledge, skills and attitudes in managing the business.

The population used is the SMEs in the Pandeglang district as many as 83 active MSMEs. To determine the sample size in this study is to use the Slovin formula model, obtained as many as 45 MSME actors. The data analysis technique uses descriptive analysis by determining the average count to find out the average personal responses or opinions of the SMEs about knowledge, skills and attitudes in managing the business. 


\section{RESULTS AND DISCUSSION}

By using a questionnaire that leads to respondents' statements of knowledge, skills and attitudes in managing a business. From the respondent's biodata, the outputs are as follows:

a. Gender

Of the 45 respondents in the sample, MSME entrepreneurs have 31 male or $68 \%$ male sex and 13 or $32 \%$ female. The majority of respondents are male

b. Age

The age of MSME worker is < 20 as many as 2 people or 4.44\%, between 21-30 years as many as 4 people or $8.89 \%$, between 31 - 40 years as many as 13 people or $28.89 \%$, between 41 - 50 years as many 22 years or $48.89 \%$ and over 50 years as many as 4 people or $8.89 \%$.

c. Status

The status of the SMEs is: 32 people are married or $71.11 \%, 9$ people are not married or $20 \%$ are single, widows/widowers are 4 people or $8.89 \%$.

d. Education

The education of SMEs in Pandeglang Regency is as follows: 11 elementary schools or $24.44 \%, 7$ junior high schools or $15.56 \%, 22$ high schools or $48.89 \%$, none with diploma and bachelor education as many as 5 people or $11.11 \%$

e. Business profile

Judging from the business profile: Crafts as much as $64.44 \%$, Food processing $88.89 \%$, Services and trade as much as $4.44 \%$, others $2.22 \%$

f. Number of Employees

MSMEs that have the number of employees: less than 5 people are $31.11 \%$, between 5 to 10 people are $44.44 \%, 11$ to 15 people are $22.22 \%$ and more than 20 people are 2.22 people.

g. Duration of Effort

Duration of business: less than 5 years $48.89 \%$, between 6 to 10 years $37.78 \%$ and 11 to 15 years $13.32 \%$

h. Working period (for workers)

For workers who work in MSMEs, they have a working period: less than 5 years $48.89 \%$, between 6 to 10 years $37.78 \%$ and 11 to 15 years $13.33 \%$.

i. One-month income

As a MSME worker viewed from a month's income: less than Rp. 1,000,000 as much as $13.33 \%$, between Rp. 1,000,000 - Rp. 5,000,000 57.78\%, between Rp. 5,000,000 - Rp. $10,000,00017.78 \%$, between Rp. 10,000 - Rp. 15. 000,000 $6.67 \%$ and more than $15,000,0004.44 \%$

j. Role in business

Judging from the role in the business: $95.56 \%$ owners and $4.44 \%$ workers

k. Family's background 
Viewed from a family background: $84.44 \%$ of traders were previously traded and $15.56 \%$ is not from merchant families

The results of the description of perceptions about knowledge, skills and behavior in managing business obtained from questionnaires are as follows:

Table 1. Descriptive Analysis of Respondents' Answers to Knowledge

\begin{tabular}{lcccccc}
\hline \multirow{2}{*}{ No } & Average & \multicolumn{4}{c}{ Percentage of Answer Frequency (\%) } & \multirow{2}{*}{ Total } \\
\cline { 3 - 6 } & & $\mathbf{1}$ & $\mathbf{2}$ & $\mathbf{3}$ & $\mathbf{4}$ & \\
\hline Knowledge 1 & 2.55 & 4.44 & 42.22 & 46.67 & 6.67 & 100 \\
\hline Knowledge 2 & 3.02 & 0 & 0 & 97.78 & 2.22 & 100 \\
\hline Knowledge 3 & 3.02 & 0 & 4.44 & 88.89 & 6.67 & 100 \\
\hline Knowledge 4 & 2.93 & 0 & 8.89 & 88.89 & 2.22 & 100 \\
\hline Knowledge 5 & 3.07 & 0 & 0 & 93.33 & 6.67 & 100 \\
\hline Knowledge 6 & 2.93 & 4.44 & 2.22 & 88.89 & 4.45 & 100 \\
\hline Knowledge 7 & 3.04 & 0 & 0 & 95.56 & 4.44 & 100 \\
\hline Knowledge 8 & 3.07 & 0 & 2.22 & 88.89 & 8.89 & 100 \\
\hline Average & 2.95 & & & & \\
\hline
\end{tabular}

Source: Data processed

From the indicator of knowledge, it has an average score towards agreement, which is 2.95, which means that it illustrates the knowledge of the MSME in managing the business quite well. The knowledge in this study includes:

1. to know and be able to run a business well

2. to know how to lead and manage work

3. to know how to establish relationships with workers

4. to know and realize the responsibilities given

5. to know the ins and outs of the product or service being sold

6. to know who my customers are

7. to know how to set strategy in the business that is being run

8. to know the whole flow and process of production or services from start of manufacture to market

Table 2. Descriptive Analysis of Respondents' Answers to Skills

\begin{tabular}{rcccccc}
\hline \multirow{2}{*}{ No } & \multirow{2}{*}{ Average } & \multicolumn{4}{c}{ Percentage of Answer Frequency (\%) } & \multirow{2}{*}{ Total } \\
\cline { 3 - 6 } & & $\mathbf{1}$ & $\mathbf{2}$ & $\mathbf{3}$ & $\mathbf{4}$ & \\
\hline Skill 1 & 2.98 & 0.00 & 6.67 & 88.89 & 4.44 & 100 \\
\hline
\end{tabular}


Journal of Management and Leadership

Vol 3, No. 2 November 2020

\begin{tabular}{lllllll}
\hline Skill 2 & 3.07 & 0.00 & 0.00 & 93.33 & 6.67 & 100 \\
\hline Skill 3 & 2.93 & 2.22 & 4.44 & 91.11 & 2.22 & 100 \\
\hline Skill 4 & 3.02 & 0.00 & 2.22 & 93.33 & 4.44 & 100 \\
\hline Skill 5 & 2.98 & 2.22 & 2.22 & 91.11 & 4.44 & 100 \\
\hline Skill 6 & 2.98 & 0.00 & 6.67 & 88.89 & 4.44 & 100 \\
\hline Skill 7 & 3.04 & 0.00 & 2.22 & 91.11 & 6.67 & 100 \\
\hline Skill 8 & 3.00 & 0.00 & 4.44 & 91.11 & 4.44 & 100 \\
\hline Skill 9 & 2.73 & 0.00 & 31.11 & 64.44 & 4.44 & 100 \\
\hline Average & 2.97 & & & & &
\end{tabular}

Source: Data processed

From the indicator of employee skills, the average score in the good direction is 2.97, which means that the SMEs are skilled enough in managing their business. In this study skills include:

1. being able to create added value in the products it sells so that it attracts customers,

2. being able to establish good relationships with customers,

3. being able to calculate the risks and losses incurred from the business,

4. being able to manage finances efficiently,

5. being able to make informed decisions,

6. being able to manage and estimate the time in business processes so that they can run smoothly

7. knowing how to compete with competitors so that the business continues to grow,

8. being able to make clear rules on the business he runs,

9. being able to carry out their duties and rules set by the owner.

Tabel 3. Analisis Deskriptif Jawaban Responden terhadap Sikap

\begin{tabular}{lcccccc}
\hline \multirow{2}{*}{ No } & \multirow{2}{*}{ Rerata } & \multicolumn{4}{c}{ Persentasi Frekuensi Jawaban $(\%)$} & \multirow{2}{*}{ Total } \\
\cline { 3 - 6 } & & $\mathbf{1}$ & $\mathbf{2}$ & $\mathbf{3}$ & $\mathbf{4}$ & \\
\hline Sikap 1 & 3.13 & 0.00 & 0.00 & 86.67 & 13.33 & 100 \\
\hline Sikap 2 & 3.02 & 0.00 & 2.22 & 93.33 & 4.44 & 100 \\
\hline Sikap 3 & 2.96 & 4.44 & 2.22 & 86.67 & 6.67 & 100 \\
\hline Sikap 4 & 3.09 & 0.00 & 0.00 & 91.11 & 8.89 & 100 \\
\hline Sikap 5 & 3.07 & 0.00 & 0.00 & 93.33 & 6.67 & 100 \\
\hline Rerata & 3.05 & & & & & \\
\hline Source: Data processed & & & & & &
\end{tabular}


The attitude indicator has a good average score of 3.0. It is the largest number of the two other indicators, namely knowledge and skills. Attitudes describe a person's characteristics. Attitudes in managing business in this study include:

1. Optimistic business will develop

2. Always motivated when working, because of the job satisfaction

3. Always think one step ahead about business

4. Always act consistently

5. Always think openly for doing business

\section{CONCLUSIONS AND SUGGESTIONS}

One indicator of the achievement of a regional development is that economic growth continues to increase significantly. It means that economic growth can continue to increase along with improvements in the economic booster sector. The success of regional development is also judged by the region's ability to meet the needs of its people and develop all the potential that exists. Each region has different potential, this can be seen from the advantages of each economic sector. Of course, with the diversity of regional characters that exist, then also different advantages from the economic sectors. By knowing the information regarding the characteristics of human resources at MSMEs in Pandeglang district, Banten province, it will be known how these characteristics can affect the development of the business being run, so that related agencies are easy to provide training or mentoring for independent MSMEs. From the results of the study, the average score of the three indicators is knowledge of 2.95, skills of 2.97 and attitude of 3.05 in managing a business that is run feasibly.

This data and information are expected to be used to identify MSME development problems. Errors in the selection of human resources will adversely affect the achievement of organizational goals. Human resources must be empowered with the management and development. The results of this study are expected to be one of the information for related agencies to make a policy to conduct training or assistance for the progress and development of MSMEs towards independent MSMEs. 


\section{REFERENCES}

Ananda, Amin Dwi., \& Susilowati, Dwi. (2017). Pengembangan Usaha Mikro Kecil Dan Menengah (Umkm) Berbasis Industri Kreatif Di Kota Malang. Jurnal Ilmu Ekonomi. Vol 1 No. 1 Hal 120-142

Dessler. Gary. (2016). Manajemen Sumber Daya Manusia. Salemba Empat

Handayani, Fitriyani., \& Juherawan, Chandra. (2018). Pengaruh UMKM terhadap perekonomian masyarkat diakses pada https://www.kompasiana.com/bb13/5af7e491caf7db30a41314f2/pengaruh-usaha-kecildan-menengah-ukm-terhadap-perekonomian-masyarakat?page=all

Simamora Hendri. (2004). Manajemen Sumber Daya Manusia, Sekolah Tinggi Ilmu Ekonomi YKPN

Sumardjo. Mahendro. (2018). Manajemen Pengembangan Manusia. Alfabeta Bandung

Undang-undang Republik Indonesia Nomor 20 Tahun 2008 Tentang Usaha Mikro, Kecil, Dan Menengah

Wilson Bangun. (2012). Manajemen Sumber Daya Manusia, Erlangga

Widjaja, Yani Restiani., et al. (2018). Peranan Kompetensi SDM UMKM Dalam Meningkatkan Kinerja UMKM Desa Cilayung Kecamatan Jatinangor, Sumedang. Jurnal Abdimas Bsi Jurnal Pengabdian Kepada Masyarakat. Vol. 1 No. 3, Hal. 465-476 